\title{
Application of a precision nutrition tool for growing and finishing pigs
}

\section{Gustavo Dias Lovato ${ }^{1}$, Marcos Martinez do Vale ${ }^{2}$, Vladimir de Oliveira ${ }^{3}$, Daniela Regina Klein ${ }^{2 *}$, Tatiane Branco ${ }^{4}$}

\author{
${ }^{1}$ Universidade Federal do Rio Grande do Sul, Departamento de Zootecnia, Porto Alegre, RS, Brazil. \\ 2 Universidade Federal do Paraná, Departamento de Zootecnia, Curitiba, PR, Brazil. \\ ${ }^{3}$ Universidade Federal de Santa Maria, Departamento de Zootecnia, Santa Maria, RS, Brazil. \\ ${ }^{4}$ Universidade Estadual de Campinas, Faculdade de Engenharia Agrícola, Departamento de Construções Rurais e Ambiência, Campinas, SP, \\ Brazil.
}

ABSTRACT - The objective of this study was to evaluate a growth model applied to adjust nutritional programs for growing and finishing pigs, in a commercial production context. The phase I (calibration) was conducted in a commercial pig production unit. The data were collected from a nutritional program, a feed program, and an animal profile. In experimental phase II, these data were entered in the InraPorc ${ }^{\circledR}$ model for simulations and to propose adjustments to the commercial nutritional program. Afterwards, the conventional nutritional program (CNP) and the adjusted nutritional program (ANP) were compared with InraPorc ${ }^{\circledR}$ simulation. Animal profile was collected by weighing $30 \%$ of pigs per stall and monitoring their feed intake in each stage. Four hundred and thirty-two pigs with an average initial body weight of $21.9 \mathrm{~kg}$ were used in a completely randomized design. There were no differences between treatments, the pig performance was affected by temperature conditions, and the fat thickness was $8 \%$ higher for CNP than ANP. In conclusion, the model has advantages to adjust growing and finishing pig nutrition programs and improve environmental and economic aspects.

Key Words: InraPorc ${ }^{\circledR}$, modeling, pig production, temperature

\section{Introduction}

Precision nutrition is a relevant concept in livestock production that uses different tools and management processes aiming to reduce losses, increase the product quality (Nääs, 2011; Pomar et al., 2009), reduce uncertainties in decisions, and optimize available resources (Mollo et al., 2009). The dynamic use of nutrients and the animal response in different production scenarios require a nutrient supply according to the diversity and purposes of production systems, aiming to improve efficiency (Pomar et al., 2009).

The InraPorc ${ }^{\circledR}$ is a precision nutrition tool (Van Milgen et al., 2008). This model integrates a dynamic, mechanistic, and deterministic approach through different aspects related to nutrition, feeding, genetics, environment, and animal behavior, serving as a decision system for the nutritional adjustment of pigs (Van Milgen et al., 2008). InraPorc ${ }^{\circledR}$

Received: August 29, 2016

Accepted: June 26, 2017

*Corresponding author: danniwk@yahoo.com.br

http://dx.doi.org/10.1590/S1806-92902017000900007

How to cite: Lovato, G. D.; Vale, M. M.; Oliveira, V.; Klein, D. R. and Branco, T. 2017. Application of a precision nutrition tool for growing and finishing pigs. Revista Brasileira de Zootecnia 46(9):755-759

Copyright (C 2017 Sociedade Brasileira de Zootecnia. This is an Open Access article distributed under the terms of the Creative Commons Attribution License (http://creativecommons.org/licenses/by/4.0/), which permits unrestricted use, distribution, and reproduction in any medium, provided the original work is properly cited. estimates nutritional requirements and animal growth, considering the variation among animals, providing greater accuracy in nutrient supply (Quiniou et al., 2009; Brossard et al., 2010) and reducing the inclusion of essential amino acids and energy in the diet, reducing diet elaboration costs (Rossi et al., 2013).

The definition of pig nutritional programs in commercial production is guided by recommendations, in which differences between production systems consider a generic form (Rostagno et al., 2005; Rostagno et al., 2011), generating situations of over- or undernutrition. The objective of this study was to evaluate a growth model applied to adjust nutritional programs for growing and finishing pigs, in a commercial production context.

\section{Material and Methods}

This study was conducted in accordance with ethical standards, in a commercial production unit in two experimental phases.

During the phase I, from November 2011 to January 2012 , the data were collected to calibrate the InraPorc ${ }^{\mathbb{B}}$ model to estimate the nutritional requirements. The pigs were a mixed group of 432 animals (barrows and gilts), from an industrial crossbreeding between AGPIC 337 males and Camborough 25 females from Agroceres PIC. Pigs were housed in a conventional shed with 16 stalls and 
27 animals each, receiving water and feed ad libitum, using commercial company nutritional programs and nutritional composition calculated according to food composition tables (CNP) of Rostagno et al. (2011). The collected data were production data [age (days), feed intake $(\mathrm{kg})$, and body weight $(\mathrm{kg})$ ] from a sampling of $30 \%$ of animals per stall. Pigs and feed were weighted at the end of each phase and daily gain, feed intake, feed conversion, and daily gain were calculated. Also, average, maximum, and minimum daily temperatures were registered.

In the experimental phase II, between March and June of 2012, we compared two nutritional programs: the conventional commercial nutrition program (CNP) and the adjusted nutritional program using the InraPorc $^{\circledR}$ model (ANP), applying the animal profile from experimental phase I (Table 1). The 432 animals were a mixed group (barrows and gilts) with the same crossbreeding used in phase I. The pigs received water and feed ad libitum. Production data [age (days), feed intake $(\mathrm{kg})$, and body weight $(\mathrm{kg})]$ were collected from a sampling of $30 \%$ of animals per stall. Pigs and feed were weighted at the end of each phase to calculate daily gain, feed intake, feed conversion, and daily gain. Average, maximum, and minimum temperatures were registered daily.

At the end of the experimental phases I and II, the animals were fasted for $10 \mathrm{~h}$ before being transported. Eight pigs were selected randomly per pen before the transport and identified for carcass evaluations. The animals were stunned electrically and bled. After slaughter and evisceration, the hot carcass weight was obtained and the carcass was cooled at $2{ }^{\circ} \mathrm{C}$ for $24 \mathrm{~h}$, to obtain cold carcass weight. After this period, carcasses were weighed again to obtain cold carcass weight. Carcass length was measured on left half carcass, from the cranial edge of the pubis symphysis to the cranioventral edge of the atlas. The fat thickness was measured, in the same half carcass, perpendicular to the midline at the last rib. Carcass dressing percentage was estimated by the following equation: $\mathrm{CY}$ $(\%)=[(\mathrm{CCW} / \mathrm{BWf}) \times 100]$, in which $\mathrm{CY}=$ carcass yield, $\mathrm{CCW}=$ cold carcass weight $(\mathrm{kg})$, and $\mathrm{BWf}=$ final body weight $(\mathrm{kg})$.

The statistical procedure was the MIXED model of SAS (Statistical Analysis System, version 9.0) with fixed effects of nutritional programs and feeding stages (except

Table 1 - Ingredients and nutritional composition of diets in the experimental phases I and II

\begin{tabular}{|c|c|c|c|c|c|c|c|c|c|c|}
\hline & \multicolumn{2}{|c|}{$\begin{array}{c}\text { Starter } \\
\text { (63 to } 72 \text { days) }\end{array}$} & \multicolumn{2}{|c|}{$\begin{array}{c}\text { Grower } 1 \\
\text { ( } 73 \text { to } 91 \text { days) }\end{array}$} & \multicolumn{2}{|c|}{$\begin{array}{c}\text { Grower } 2 \\
\text { (92 to } 106 \text { days) }\end{array}$} & \multicolumn{2}{|c|}{$\begin{array}{c}\text { Finisher } 1 \\
\text { (107 to } 121 \text { days) }\end{array}$} & \multicolumn{2}{|c|}{$\begin{array}{c}\text { Finisher } 2 \\
\text { (122 to } 156 \text { days) }\end{array}$} \\
\hline & CNP & ANP & CNP & ANP & CNP & ANP & $\mathrm{CNP}$ & ANP & CNP & ANP \\
\hline \multicolumn{11}{|l|}{ Ingredient ( $\mathrm{g} / \mathrm{kg}$ as fed) } \\
\hline Corn & 395.2 & 439.2 & 553.2 & 436.2 & 621.2 & 561.2 & 631.2 & 612.2 & 516.9 & 557.9 \\
\hline Soybean meal & 280 & 273 & 260 & 260 & 233 & 225 & 217 & 212 & 231 & 205 \\
\hline Broken rice & 250 & 225 & 100 & 130 & 60 & 93 & - & 80 & 80 & 117 \\
\hline Rice bran & - & 30 & - & 125 & - & 83 & 70 & 55 & 90 & 95 \\
\hline Meat and bone meal & 23 & 16 & 40 & 24 & 40 & 20 & 37 & 19 & 38 & 4 \\
\hline Soybean oil & 26 & - & 28 & 9 & 28 & - & 26 & 2 & 25 & 2 \\
\hline Limestone & 9.0 & 7.0 & 4.5 & 6.0 & 4.2 & 6.0 & 5.5 & 8.0 & 5.0 & 7.7 \\
\hline Salt & 4.0 & 4.1 & 3.9 & 3.7 & 4.0 & 4.1 & 3.8 & 4.0 & 3.9 & 4.0 \\
\hline L-lysine $\mathrm{HCl}$ & 6.0 & 1.7 & 4.0 & 1.7 & 4.0 & 3.0 & 4.0 & 3.0 & 3.9 & 2.9 \\
\hline DL-methionine & 1.4 & - & 1.3 & 0.3 & 1.1 & 0.6 & 1.2 & 0.8 & 1.3 & 0.4 \\
\hline L-treonine & 1.4 & - & 1.3 & 0.3 & 0.9 & 0.5 & 1.0 & 0.7 & 1.2 & 0.3 \\
\hline Mineral vitamin ${ }^{1}$ & 4.0 & 4.0 & 3.8 & 3.8 & 3.6 & 3.6 & 3.3 & 3.3 & 3.5 & 3.5 \\
\hline Ractopamine & - & - & - & - & - & - & - & - & 0.25 & 0.25 \\
\hline \multicolumn{11}{|l|}{ Calculated composition (g/kg) } \\
\hline Dry matter & 897.0 & 885.0 & 892.0 & 907.0 & 896.0 & 911.0 & 904.0 & 892.0 & 902.0 & 887.0 \\
\hline Metabolizable energy (ME; kcal/kg) & 3,319 & 3,224 & 3,343 & 3,224 & 3,343 & 3,200 & 3,295 & 3,200 & 3,295 & 3,176 \\
\hline Crude protein & 198.0 & 194.0 & 198.0 & 197.0 & 188.0 & 181.0 & 184.0 & 175.0 & 191.0 & 170.0 \\
\hline Lysine $^{2}$ & 11.4 & 9.7 & 10.3 & 9.3 & 9.7 & 8.9 & 9.4 & 8.6 & 9.8 & 8.2 \\
\hline Lysine:ME (g/kcal) & 257.90 & 229.25 & 231.64 & 217.31 & 217.31 & 210.14 & 212.53 & 200.59 & 222.08 & 193.43 \\
\hline Methionine + cystine $^{2}$ & 6.6 & 5.5 & 6.4 & 5.7 & 6.0 & 5.6 & 5.9 & 5.6 & 6.2 & 5.2 \\
\hline Methionine $^{2}$ & 3.8 & 2.7 & 3.7 & 2.9 & 3.4 & 3.0 & 3.4 & 3.1 & 3.6 & 2.6 \\
\hline Cystine $^{2}$ & 2.7 & 2.8 & 2.7 & 2.7 & 2.6 & 2.6 & 2.4 & 2.5 & 2.6 & 2.5 \\
\hline Treonine $^{2}$ & 7.2 & 6.0 & 7.0 & 6.3 & 6.5 & 6.0 & 6.5 & 6.0 & 6.8 & 5.4 \\
\hline Calcium & 7.9 & 6.1 & 7.4 & 6.5 & 7.4 & 6.0 & 7.4 & 6.6 & 7.4 & 5.1 \\
\hline Total phosphorus & 5.5 & 4.9 & 5.6 & 6.5 & 5.5 & 5.7 & 6.3 & 5.3 & 6.6 & 5.4 \\
\hline Digestible phosphorus $^{2}$ & 3.7 & 2.8 & 3.9 & 3.4 & 3.9 & 3.1 & 3.9 & 3.0 & 4.0 & 2.4 \\
\hline
\end{tabular}

CNP - conventional nutritional program; ANP - adjusted nutritional program through InraPorc ${ }^{\circledR}$ model.

${ }^{1}$ Supplied per kg: 55,000 mg Fe; 85,000 mg Cu; 20,000 mg Mn; 250 mg Co; 500 mg I; 150 mg Se; 42,000 mg Zn; 5,000,000 IU vitamin A; 1,300,000 IU vitamin D3; 15,000 IU vitamin E; 1,500 mg vitamin K3; $800 \mathrm{mg}$ vitamin B1; 3,000 mg vitamin B2; 1,200 mg vitamin B6; 15,000 mcg vitamin B12; 250 mg folic acid; 7,000 mg pantothenic acid; $15,000 \mathrm{mg}$ niacin; phytase $(50 \mathrm{~g} /$ ton of feed $)$ with activity of $10,000 \mathrm{FTU} / \mathrm{g}$.

2 True ileal digestible amino acid. 
for carcass traits). A structure selection test was conducted using Bayesian information criterion to determine the best model. Whenever differences were observed, means between nutritional programs and feeding stages were compared using the LSMEANS procedure. Nutritional program $\times$ feeding stage interaction was decomposed when significant at the $5 \%$ probability level. The estimated values of pig performance obtained by the model were compared with the observed means to evaluate the model accuracy and predict the performance with the $t$ test at the $5 \%$ probability level, in which insignificant differences represented adequate model accuracy.

\section{Results}

No differences were found ( $\mathrm{P}>0.05$ ) (Table 2) among treatments for the performance variables.

Different temperatures were observed during the experimental phases I and II, which can have influence on the performance of CNP and ANP (Table 3).

The pig performances were similar between the models ANP and CNP (Table 4); however, the model had an adequate accuracy to estimate average body weight in growth stage 1 (grower 1) $(\mathrm{P}>0.05)$.

The nutritional programs did not influence $(\mathrm{P}>0.05)$ the carcass analysis, except for the fat thickness of the pigs fed ANP, which was $1.6 \mathrm{~mm}$ lower $(\mathrm{P}<0.05)$ as compared with treatment CNP (Table 5).

\section{Discussion}

No differences between treatments agree with other researchers who used the $\operatorname{InraPorc}^{\circledR}$ model as a tool to adjust nutritional programs (Quiniou et al., 2009; Rossi et al., 2013).

Differences between the observed values and the values estimated by the model for body weight and body weight gain is explained by the fact that average daily feed intake has significant differences in finisher 1 and finisher 2 stages $(\mathrm{P}<0.01)$. The variation in feed intake can be attributed to the different environmental conditions between the experimental phases I and II. High environmental temperatures reduce voluntary feed intake in pigs during heat stress (Quiniou et al., 2001; Huynh et al., 2005; Kiefer et al., 2010; Batista et al., 2011) because the intake mechanisms are regulated for the short and long-term processes, which influence the partition of energy between maintenance and deposition (Hauschild et al., 2010; Batista et al., 2011; Hauschild et al., 2012; Rossi et al., 2013; Warpechowski et al., 2014). The InraPorc ${ }^{\circledR}$ deterministic $^{2}$ model characterizes the pig in thermal comfort, in heat stress, or under other factors that influence the voluntary feed intake (Van Milgen et al., 2008; Hauschild et al., 2012; Rossi et al., 2013), but does not consider environmental effects directly. However, if the animal profile is adjusted in specific climatic conditions, its requirements and the nutritional adjustment are more accurate.

Analyzing the carcass, nutritional programs only affect fat thickness, indicating efficient adjustment of dietary nutrients, despite the influence of temperature on feed intake; similar results were found by Quiniou et al. (2009).

Table 2 - Performance of pig with conventional nutritional program (CNP) and adjusted nutritional program through InraPorc ${ }^{\circledR}$ model (ANP) during grower and finisher phases

\begin{tabular}{|c|c|c|c|c|}
\hline \multirow{2}{*}{ Variable } & \multicolumn{2}{|c|}{ Nutritional program } & \multirow{2}{*}{ SME } & \multirow{2}{*}{ P-value } \\
\hline & $\mathrm{CNP}$ & ANP & & \\
\hline Initial body weight (kg) & 21.90 & 21.80 & 0.490 & 0.97 \\
\hline \multicolumn{5}{|c|}{63 to 72 days } \\
\hline Body weight (kg) & 29.20 & 29.10 & 0.399 & 0.99 \\
\hline ADFI (kg/day) & 1.25 & 1.21 & 0.091 & 0.42 \\
\hline ADG (kg/day) & 0.80 & 0.81 & 0.093 & 0.98 \\
\hline $\mathrm{F}: \mathrm{G}(\mathrm{kg} / \mathrm{kg})$ & 1.58 & 1.52 & 0.112 & 0.55 \\
\hline \multicolumn{5}{|c|}{73 to 91 days } \\
\hline Body weight (kg) & 48.40 & 47.70 & 0.888 & 0.36 \\
\hline ADFI (kg/day) & 1.94 & 1.91 & 0.056 & 0.58 \\
\hline ADG (kg/day) & 1.07 & 1.03 & 0.051 & 0.39 \\
\hline $\mathrm{F}: \mathrm{G}(\mathrm{kg} / \mathrm{kg})$ & 1.82 & 1.87 & 0.063 & 0.45 \\
\hline \multicolumn{5}{|c|}{92 to 106 days } \\
\hline Body weight (kg) & 67.40 & 67.10 & 0.702 & 0.61 \\
\hline ADFI (kg/day) & 2.39 & 2.48 & 0.053 & 0.11 \\
\hline ADG (kg/day) & 1.27 & 1.29 & 0.072 & 0.68 \\
\hline $\mathrm{F}: \mathrm{G}(\mathrm{kg} / \mathrm{kg})$ & 1.91 & 1.92 & 0.087 & 0.83 \\
\hline \multicolumn{5}{|c|}{107 to 121 days } \\
\hline Body weight (kg) & 91.80 & 91.30 & 1.468 & 0.73 \\
\hline ADFI (kg/day) & 2.84 & 2.87 & 0.083 & 0.71 \\
\hline ADG (kg/day) & 1.28 & 1.27 & 0.068 & 0.91 \\
\hline $\mathrm{F}: \mathrm{G}(\mathrm{kg} / \mathrm{kg})$ & 2.23 & 2.27 & 0.103 & 0.63 \\
\hline \multicolumn{5}{|c|}{122 to 156 days } \\
\hline Body weight (kg) & 121.60 & 120.90 & 1.409 & 0.33 \\
\hline ADFI (kg/day) & 2.99 & 2.98 & 0.063 & 0.86 \\
\hline ADG (kg/day) & 0.93 & 0.90 & 0.043 & 0.48 \\
\hline $\mathrm{F}: \mathrm{G}(\mathrm{kg} / \mathrm{kg})$ & 3.23 & 3.35 & 0.181 & 0.51 \\
\hline
\end{tabular}

ADFI - average daily feed intake; ADG - average daily weight gain; F:R - feed:gain ratio; SME - square means error.

${ }^{1}$ Probability at $5 \%$ of significance.

Table 3 - Average temperatures observed during experimental phases I and II

\begin{tabular}{lcc}
\hline Temperature $\left({ }^{\circ} \mathrm{C}\right)$ & Phase I & Phase II \\
\hline Minimum & 19.2 & 13.5 \\
Average & 25.6 & 19.5 \\
Maximum & 32.1 & 25.6 \\
\hline
\end{tabular}


Table 4 - Differences ${ }^{1}$ observed between phase I and phase II diets

\begin{tabular}{|c|c|c|c|c|c|}
\hline Variable $^{2}$ & $\begin{array}{c}\text { Starter } \\
\text { (63 to } 72 \text { days) }\end{array}$ & $\begin{array}{c}\text { Grower } 1 \\
\text { (73 to } 91 \text { days) }\end{array}$ & $\begin{array}{c}\text { Grower } 2 \\
\text { (92 to } 106 \text { days) }\end{array}$ & $\begin{array}{c}\text { Finisher } 1 \\
\text { (107 to } 121 \text { days) }\end{array}$ & $\begin{array}{c}\text { Finisher } 2 \\
\text { (122 to156 days) }\end{array}$ \\
\hline BW (kg) & $-0.99 * * *$ & -0.27 & $3.39 * * *$ & $5.32 * *$ & $3.65 *$ \\
\hline ADFI (kg/day) & -0.04 & -0.08 & 0.01 & $0.21 * *$ & $0.26 * *$ \\
\hline ADG (kg/day) & $-0.06 * *$ & -0.01 & $0.07 * *$ & $0.08 * *$ & -0.01 \\
\hline
\end{tabular}

BW - body weight; ADFI - average daily feed intake; ADG - average daily gain.

${ }^{1}$ Significantly different by the $t$ test.

${ }^{2}$ At the end of phase.

$* \mathrm{P}<0.05$.

$* * \mathrm{P}<0.01$

$* * * \mathrm{P}<0.001$

Table 5 - Carcass traits of pig feed with conventional nutritional program $(\mathrm{CNP})$ in phase I and adjusted nutritional program by InraPorc ${ }^{\circledR}$ model (ANP) in phase II

\begin{tabular}{lcccc}
\hline \multirow{2}{*}{ Variable } & \multicolumn{2}{c}{ Nutritional program } & \multirow{2}{*}{ SEM } & P-value \\
\cline { 2 - 3 } & CNP & ANP & & \\
\hline Hot carcass weight $(\mathrm{kg})$ & 89.50 & 88.60 & 1.56 & 0.57 \\
Cold carcass weight $(\mathrm{kg})$ & 87.10 & 86.20 & 1.45 & 0.55 \\
Losses during cooling $(\mathrm{kg})$ & 2.37 & 2.35 & 0.24 & 0.93 \\
Carcass yield $(\%)$ & 72.00 & 72.10 & 1.09 & 0.91 \\
Carcass length $(\mathrm{cm})$ & 98.90 & 98.50 & 0.72 & 0.62 \\
Fat thickness $(\mathrm{mm})$ & 20.50 & 18.90 & 3.44 & $0.04 *$ \\
\hline
\end{tabular}

SEM - standard error of the mean.

${ }^{1}$ Probability at $5 \%$ of significance.

* Significantly different at $\mathrm{P}<0.05$.

The use of a precision tool, such as the InraPorc ${ }^{\circledR}$ model, can alter the feed formulation, improving environmental and economic aspects. Further studies related to the response of pigs to temperature, in similar production systems to this study, are needed to improve the ability and accuracy of growth models. This requires establishing a methodology to enter the animal profile information to be used in the parameterization of the growth model in studied situations.

\section{Conclusions}

Pig performance is not affected with adjusted nutritional programs for growing and finishing pigs, but the adjusted nutritional program is adequate to estimate average body weight in grower phase and decrease fat thickness. The model has advantages to adjust growing and finishing pig nutrition programs and improve environmental and economic aspects.

\section{Acknowledgments}

We acknowledge the Coordenação de Aperfeiçoamento de Pessoal de Nível Superior (CAPES) for providing scholarships and Dr. Paulo Alberto Lovatto (in memoriam) for the teachings and incentive for the accomplishment of this work.

\section{References}

Batista, R. M.; Oliveira, R. F. M.; Donzele, J. L.; Oliveira, W. P.; Lima, A. L. and Abreu, M. L. T. 2011. Lisina digestível para suínos machos castrados de alta deposição de carne submetidos a estresse por calor dos 30 aos $60 \mathrm{~kg}$. Revista Brasileira de Zootecnia 40:1925-1932.

Brossard, L. ; Quiniou, N.; Dourmad, J.; Salaün, Y. and Van Milgen, J. 2010. Définir des stratégies alimentaires alliant performance économique et impact environnemental grâce à la modélisation du groupe de porcs en croissance. Journées Recherche Porcine 42:131-132.

Hauschild, L.; Lovatto, P. A.; Pomar, J. and Pomar, C. 2012. Development of sustainable precision farming systems for swine: Estimating realtime individual amino acid requirements in growing-finishing pigs. Journal of Animal Science 90:2255-2263.

Hauschild, L.; Pomar, C. and Lovatto, P. A. 2010. Systematic comparison of the empirical and factorial methods used to estimate the nutrient requirements of growing pigs. Animal 4:714-723.

Huynh, T. T. T.; Aarnink, A. J. A.; Gerrits, W. J. J.; Heetkamp, M. J. H.; Canh, T. T.; Spoolder, H. A. M.; Kemp, B. and Verstegen, M. W. A. 2005. Thermal behaviour of growing pigs in response to high temperature and humidity. Applied Animal Behaviour Science 91:1-16.

Kiefer, C.; Moura, M. S.; Silva, E. A.; Santos, A. P.; Silva, C. M.; Luz, M. F. and Nantes, C. L. 2010. Respostas de suínos em terminação mantidos em diferentes ambientes térmicos. Revista Brasileira de Saúde e Produção Animal 11:496-504.

Mollo, M.; Vendrametto, O. and Okano, M. 2009. Precision livestock tools to improve products and processes in broiler production: a review. Revista Brasileira de Ciência Avícola 11:211-218.

Nääs, I. A. 2011. Uso de técnicas de precisão na produção animal. Revista Brasileira de Zootecnia 40(supl. especial):358-364

Pomar, C.; Hauschild, L.; Zhang, G.-H.; Pomar, J. and Lovatto, P. A. 2009. Applying precision feeding techniques in growingfinishing pig operations. Revista Brasileira de Zootecnia 38(supl. especial):226-237.

Quiniou, N.; Noblet, J.; van Milgen, J. and Dubois, S. 2001. Modelling heat production and energy balance in group-housed growing pigs exposed to low or high ambient temperatures. British Journal of Nutrition 85:97-106.

Quiniou, N.; Allain, C. and Vautier, A. 2009. Evaluation zootechnique d'une stratégie alimentaire biphase établie via le logiciel InraPorc $\mathbb{R}$ et appliquée sur des porcs issus de verrats Pietrain ou Large White $\times$ Piétrain. Journées Recherche Porcine 41:101-108.

Rossi, C. A. R.; Lovatto, P. A.; Lehnen, C. R.; Fraga, C. N.; Lovato, C. D. and Ceron, M. S. 2013. Dietas ajustadas para suínos através 


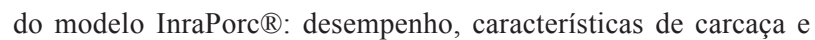
impacto econômico. Ciência Rural 43:689-695.

Rostagno, H. S.; Albino, L. F. T. and Donzele, J. L. 2005. Tabelas brasileiras para aves e suínos; composição de alimentos e exigências nutricionais. Editora UFV, Viçosa, MG.

Rostagno, H. S.; Albino, L. F. T.; Donzele, J. L.; Gomes, P. C.; Oliveira, R. F.; Lopes, D. C.; Ferreira, A. S.; Barreto, S. L. T. and Euclides, R. F. 2011. Tabelas brasileiras para aves e suínos; composição de alimentos e exigências nutricionais. Editora UFV, Viçosa, MG.
Van Milgen, J.; Valancogne, A.; Dubois, S.; Dourmad, J. Y.; Sève, B. and Noblet, J. 2008. InraPorc: A model and decision support tool for the nutrition of growing pigs. Animal Feed Science and Technology 143:387-405.

Warpechowski, M. B.; Brossard, L.; Hauptli, L.; Pierozan, E. A.; Quadros, J. A.; Muchalak, D. N. and Machado, M. F. 2014. Evaluation du modèle nutritionnel InraPorc pour un système de finition de porcs lourds du sud du Brésil. Journées Recherche Porcine 46:133-134. 